INTERNATIONAL JOURNAL OF MULTIDISCIPLINARY RESEARCh AND ANALySis

ISSN(print): 2643-9840, ISSN(online): 2643-9875

Volume 04 Issue 01 January 2021

DOI: 10.47191/ijmra/v4-i1-05, Impact Factor: 5.522

Page No.- 28-37

\title{
Characterization and Classification of Geotechnical Index Properties of Shallow Soil Deposits at Oworoshoki Area, Kosofe Local Government, Lagos, Nigeria
}

\author{
I.T. Peni ${ }^{1}$, A.M. Mustapha ${ }^{2}$ \\ ${ }^{1}$ Sokoto Energy Research Centre, Usmanu Danfodiyo University, Sokoto, Nigeria. \\ ${ }^{2}$ Civil Engineering Department, Federal University of Technology, Minna, Niger, Nigeria
}

ABSTRACT: The study of geotechnical index properties of soils in Oworoshoki, Kosofe, Lagos State was conducted to characterize and classify the index properties of soil samples. Disturbed and undisturbed soils were collected at different shallow depths (1m, $2 \mathrm{~m}$ and $3 \mathrm{~m}$ ) from the study area and laboratory test was conducted. The laboratory test conducted includes natural moisture content, atterberg limits (liquid limit and plastic limit), particle size distribution, specific gravity, unit weight and hydrometer. The results of the test were gotten: natural moisture content as $23.5 \%, 24.5 \%$ and $25.3 \%$, liquid limits (LL) $28.68 \%, 26.64 \%$ and $29.10 \%$, Oworoshoki is non-plastic for the three depths i.e. plastic limit (PL) is 0 , particle size distribution percentage passing through BS \#200 (0.075mm) are $95.97 \%, 97.97 \%, 98.10 \%$ and this shows that the soil sample contain much silt, the samples are non-plastic for all depths $(1 \mathrm{~m}, 2 \mathrm{~m}$ and $3 \mathrm{~m})$, specific gravity as $2.61,2.55$ and 2.60 , unit weight as $17.5 \mathrm{KN} / \mathrm{m}^{3}, 18.1 \mathrm{kn} / \mathrm{m}^{3}$ and $18.9 \mathrm{KN} / \mathrm{m}^{3}$ and hydrometer percentage passing through BS \#200 $(0.075 \mathrm{~mm})$ as $95.97 \%$ at $1.0 \mathrm{~m}$ depth, $97.97 \%$ at $2.0 \mathrm{~m}$ depth and $98.10 \%$ at $3.0 \mathrm{~m}$ depth. Hydrometer test was conducted because $95.97 \%$ passes sieve $0.075 \mathrm{~mm}$. This shows that the soil contain high amount of silt. Soils from depth $1.0 \mathrm{~m}, 2.0 \mathrm{~m}$ and $3.0 \mathrm{~m}$ are non-plastic (NP) because the $\mathrm{Plastic}$ Index (PI=0) and the soil samples are classified as A - 3 according to American Association of State Highway and Transportation Officials (AASHTO) System.

KEYWORDS: Soil samples, natural moisture content, Atterberg limits, particle size distribution, specific gravity.

\section{INTRODUCTION}

Oworoshoki is an area found in Kosofe local government in Lagos State. Lagos State is located in the western part of Nigeria. It shares boundaries with Ogun State both in the north and east and is bounded on the west by Republic of Benin. In the south, it stretches for $180 \mathrm{~km}$ along the coast to the Atlantic Ocean. It occupies an area of $3,577 \mathrm{~km}^{2}$. It falls on latitude $6^{0} 27^{\prime} 10.8^{\prime \prime} \mathrm{N}$ and longitude $3^{0} 23^{\prime} 44.99^{\prime \prime E}$. Characterization and classification of geotechnical index properties of the soil are essential to define its main potentials and restrictions. Index properties of soil are these properties of soil that indicate the type and condition of the soil and provide a relationship to structural properties. It can also be define as properties which facilitate identification and classification of soils for engineering purposes. This study is only concern with these index properties and characterizing it. Generally, index properties of soils are determined by laboratory testing on soil samples obtained from the site (Yoon et al., 2015). The relationship between all engineering infrastructure and their foundation soil is too important to be ignored. A considerable increase in soil utility for engineering works is expected as the country aspires toward improving infrastructural development. Incessant occurrence of road pavement failure and building collapse has made it imperative for proper understanding of the geotechnical properties of soils. Lack of geotechnical information has result the collapse of some buildings in Lagos State, Oyo State, Anambara State, Plateau State etc of Nigeria between 2018 and 2019. Expansive soil cause significant damage to structure and roadways by cyclic shrink-swell within the active zone of soil (Christodoulias, 2015).Expansive soils cause billions of dollars of damage to homes and property each year (Christodoulias, 2015).The significance of swelling soils in relation to geotechnical problems is now widely recognized. Geotechnical problems arising from expansive unsaturated soils are well demonstrated by many case histories all over the world, especially in geographical zones having arid, semi-arid and tropical climatologically conditions (Christodoulias,2015).The existence of specific expansive minerals in the clay soil related to the 


\section{Characterization and Classification of Geotechnical Index Properties of Shallow Soil Deposits at Oworoshoki Area, Kosofe Local Government, Lagos, Nigeria}

climatologically conditions, seasonable variation of rainfall precipitation (wet and dry periods) and fluctuation of water table in Mediterranean countries, has resulted to induce unexpected shrinkage and swelling movements with all the unfavorable consequences. It was observed that light industrial structures and small buildings suffer from heaving, road pavements to develop shrinkage cracks, canal lining and low embankments resting on swelling soil or embankments constructed with swelling soil, suffer distortion and cracking. If the propensity of a soil to shrink and swell is known before construction, shrinkage limit results can give information to design engineers, because if it is known the ability of soil to shrink or swell before construction, damage can be avoided. Geotechnical properties of soils influence the stability of civil engineering structures. The civil engineering structures like building, bridge, highway, tunnel, dam, tower, etc. are founded below or on the surface of the earth (Surendra, 2017). For their stability, suitable foundation soil is required. To check the suitability of soil to be used as foundation or as construction materials, its properties are required to be assessed (Laskar and Pal,2012).Clay is predominant in most of the sub grade soils of Nigeria. Due to the relative abundance of these soil and ease of acquisition they have wide application in engineering construction works (Oyediran, 2011). Identification and classification can only be achieved through atterberge limit test (determination of liquid limit, plastic limit and linear shrinkage), specific gravity of soil particles, particle size distribution etc. For engineering purpose, soil is defined as any loose sedimentary deposit such as gravel, sand, silt, clay or mixture of these materials (smith, 1994). It is made up of various size of particles parked together with spaces between the particles known as voids. The voids are generally the mixture of air and water. A whole of laboratory test can be performed on soils to measure a wide variety of soil properties. Some soil properties are intrinsic to the composition of the soil matrix and are not affected by sample disturbance, while other properties depend on the structure of the soil as well as its composition, and are tested on relatively disturbed samples (Rorome and Ekeocha, 2015).Some soil test measure direct properties of the soil, while others measures index properties which provide useful information about the soil without direct measuring of the property desired (Rorome and Ekeocha, 2015). The previous work done in this area was also carried out by Akpokodje (1989; 2001) where he investigated the soil properties and pavement performance in the Niger Delta; the incidence of pavement failure of various roads in the Niger Delta, and correlated this with various factors such as rainfall, grain size distribution.(Rorome and Ekeocha, 2015) have conducted a study on geotechnical index properties of soil from various locations in Warri, Delta State. From his laboratory test results; Moisture Content (MC) ranges from 8.1- 26.9\%, Liquid Limit (LL) ranges from 22.0 - 38\%, Plasticity Limit (PL) ranges from $19.5-22.4 \%$ and Plastic Index (PI) ranges from 2.1-17.9\%. He observed that the sample collected from the locations contain high percentage of fine soil (silt clay and fine sand) without gravel sized particles which was classified based on Unified Soil Classification Schemes (USC) as poorly graded, well drained, intermediate plasticity and medium swelling potential soil since it does not contain particles of all sizes. (Oke and Amadi, 2008; Nwankwoala and Warmate,2014) have highlighted that, assessment of geotechnical properties of subsoil at project site is necessary for generating relevant input data for design and construction of foundations for the proposed structures. Oghenero et al (2014) have stated that proper design and construction of civil engineering structures prevent an adverse environmental impact or structural failure or post construction problems. Information about the surface and sub-surface features is essential for the design of structures and for planning construction techniques. For complex projects involving heavy structures, such as bridges, dams, multi-storey buildings, it is essential to have detail exploration. The purpose of detailed explorations is to determine the engineering properties of the soils for different strata (Arora, 2008). Lack of understanding the properties of the soil can lead to the construction errors. The suitability of soil for a particular use should be determined based on its engineering characteristics and not on visual inspection or apparent similarity to other soils. The loading capability of soil depends upon the type of soil. Generally, fine grained soils have a relative smaller capacity in bearing of load than the coarser grained soils (Jain et al., 2015).Plasticity index and liquid limit are the important factors that help an engineer to understand the consistency or plasticity of clay (Surendra, 2017).

\section{MATERIALS AND METHODS}

Shallow soil samples (disturbed and undisturbed) at different depths $(1 \mathrm{~m}, 2 \mathrm{~m}$ and $3 \mathrm{~m})$ were collected from the study area. The disturbed samples were collected using hand trowel, digger, hoe and polythene bags while the undisturbed samples were collected using short pipes (samplers) by stroking each pipe into the ground completely to the level of the depth with a hammer. They were removed, wrapped and labeled for identification then put into a polythene bag which is airtight to maintain moisture content before laboratory test. The two samples were used for determining natural moisture content, specific gravity, sieve analysis, Atterberg limits and unit weight in the laboratory. Global Positioning System (GPS) was used to locate the coordinate of the site. American Association of State Highway and Transportation Officials (AASHTO) system was the method of soil classification used for classifying the soil sample. 
Characterization and Classification of Geotechnical Index Properties of Shallow Soil Deposits at Oworoshoki Area, Kosofe Local Government, Lagos, Nigeria

\section{Study Area}

Oworoshoki area, Kosofe local government: It falls on latitude $6^{0} 27^{\prime} 10.8^{\prime \prime} \mathrm{N}$ and longitude $3^{0} 23^{1} 44.99^{\prime \prime} \mathrm{E}, 12 \mathrm{~km}$ from Lagos. The study area is as shown with an arrow indicating in Plate1 bellow.

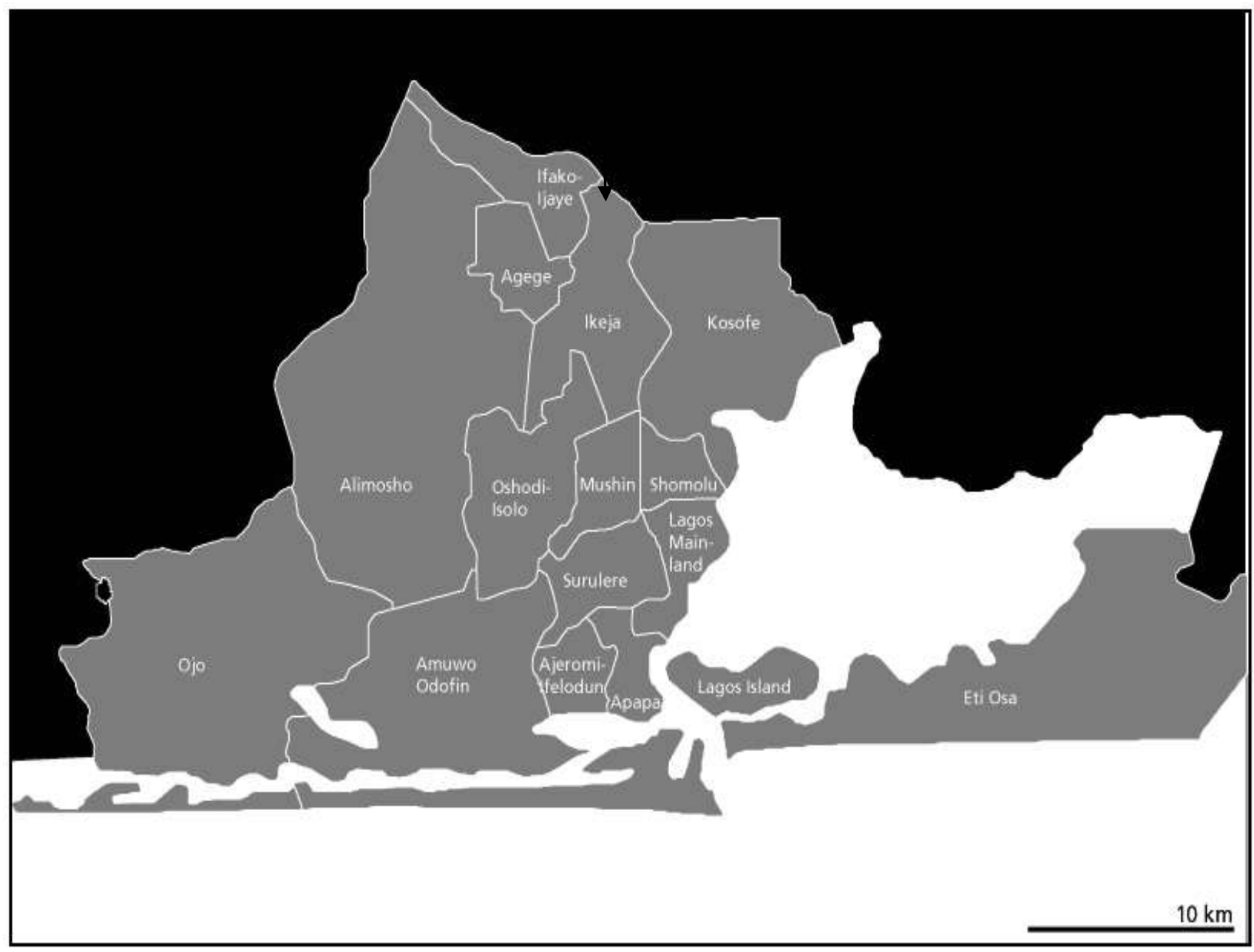

Plate 1: Map of Lagos State showing the Study Area

\section{RESULTS AND DISCUSSION}

\section{Natural Moisture Content}

Table 1 below shows the Natural Moisture content of sample at $1 \mathrm{~m}, 2.0 \mathrm{~m}$ and $3 \mathrm{~m}$ depth.

Table 1 Natural Moisture content of sample at $1.0 \mathrm{~m}, 2.0 \mathrm{~m}$ and $3.0 \mathrm{~m}$ depth

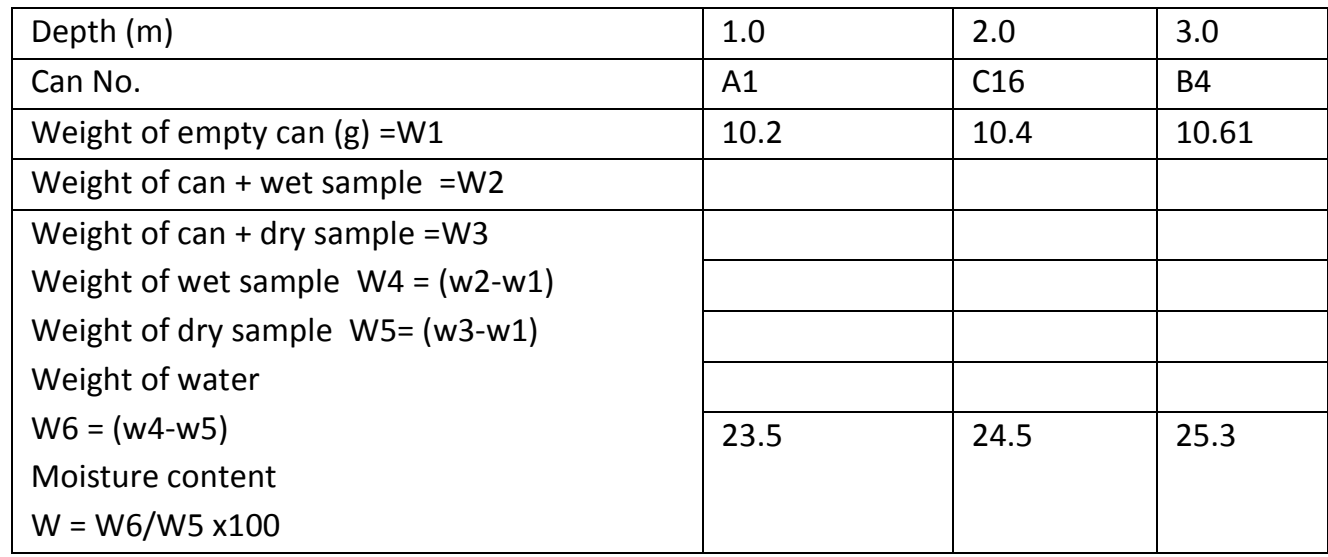


Characterization and Classification of Geotechnical Index Properties of Shallow Soil Deposits at Oworoshoki Area, Kosofe Local Government, Lagos, Nigeria

Figure 1. shows the Natural Moisture Content Graph of moisture content against depth of sample at $1.0 \mathrm{~m}, 2.0 \mathrm{~m}$ and $3.0 \mathrm{~m}$ depth.

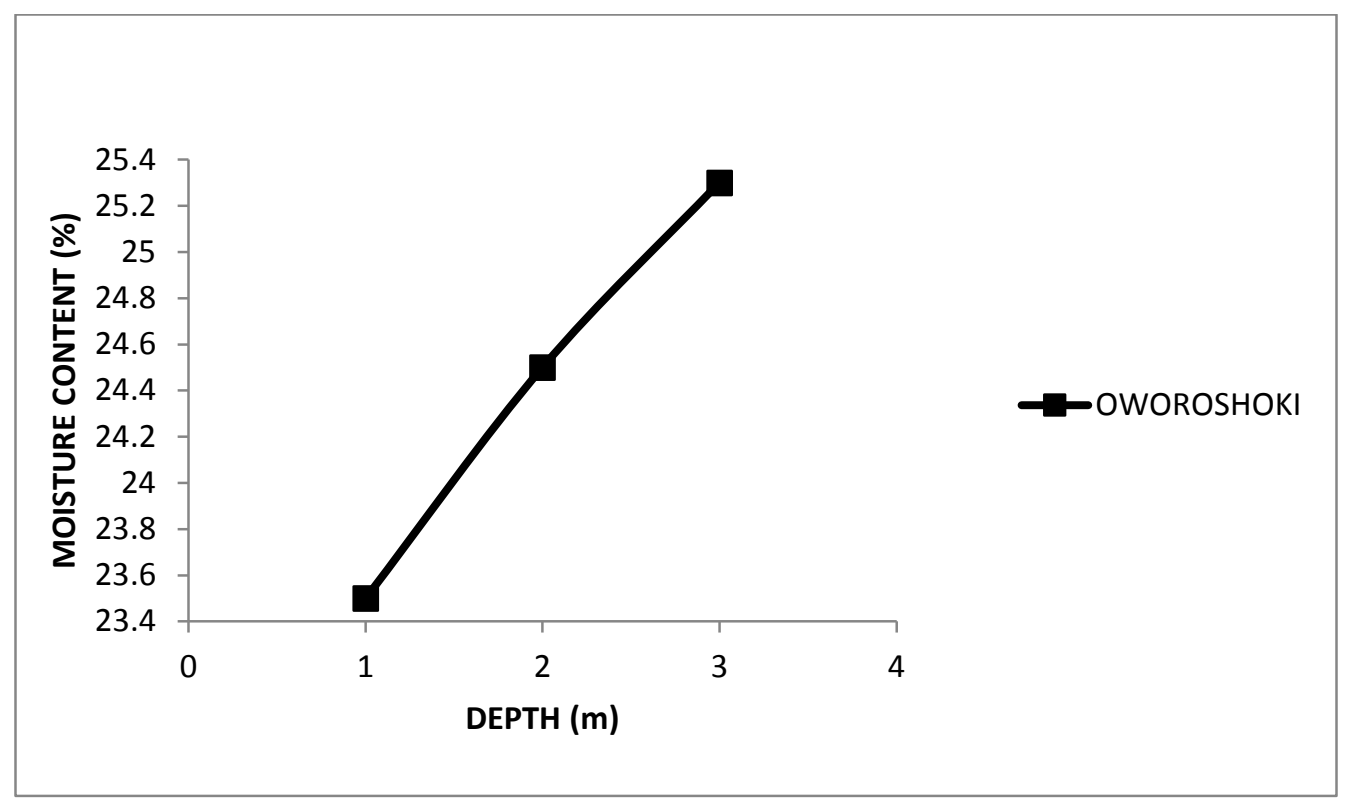

Figure 1: Natural Moisture Content

\section{Atterberg Limits}

Table 2, 3 and 4 below shows Liquid limit cone penetrometer method at $1 \mathrm{~m}, 2.0 \mathrm{~m}$ and $3 \mathrm{~m}$ depth respectively.

Table 2. Liquid limit cone penetrometer method at $1.0 \mathrm{~m}$ depth

\begin{tabular}{|l|l|l|l|l|l|l|l|}
\hline \multicolumn{5}{|l|}{ Liquid Limit } & Plastic Limit \\
\hline Con No & 1 & 2 & 3 & 4 & 5 & 1 & 2 \\
Penetration & 3.9 & 8.8 & 12.5 & 18.7 & 22.5 & & \\
Can weight & 37.95 & 37.75 & 37.60 & 37.36 & 37.58 & & \\
Weight of can +wet soil & 58.26 & 63.21 & 60.69 & 62.71 & 58.2 & & \\
Weight of can +dry soil & 55.04 & 58.54 & 55.98 & 57.24 & 53.51 & & \\
Weight of moisture & 3.22 & 4.67 & 4.71 & 5.47 & 4.71 & & \\
Weight of dry soil & 17.09 & 20.79 & 18.38 & 19.88 & 15.93 & & \\
Moisture content & 18.84 & 22.46 & 25.63 & 27.52 & 29.57 & 0.00 & 0.00 \\
Liquid Limit & 28.68 & $\%$ & Average & Plastic & Limit & 0.00 & $0 \%$ \\
\hline
\end{tabular}

Table 3. Liquid Limit cone penetrometer method at 2.0m depth

\begin{tabular}{|c|c|c|c|c|c|c|c|}
\hline & \multicolumn{5}{|c|}{ Liquid Limit } & \multicolumn{2}{|c|}{ Plastic limit } \\
\hline Can No & 1 & 2 & 3 & 4 & 5 & 1 & 2 \\
\hline Penetration & 5.6 & 10.7 & 15.2 & 19.0 & 23.2 & & \\
\hline Can weight & 37.21 & 38.55 & 37.75 & 38.03 & 37.68 & & \\
\hline Weight of can +wet soil & 38.33 & 66.72 & 66.86 & 64.63 & 67.40 & & \\
\hline Weight of can + dry soil & 54.93 & 61.56 & 61.19 & 59.07 & 60.92 & & \\
\hline Weight of moisture & 3.40 & 5.16 & 5.67 & 5.56 & 6.48 & & \\
\hline Weight of dry soil & 17.72 & 23.01 & 23.44 & 21.04 & 23.24 & & \\
\hline Moisture content & 19.19 & 22.13 & 21.19 & 26.13 & 27.88 & 0.00 & 0.00 \\
\hline Liquid limit & \multicolumn{2}{|c|}{$26.64 \%$} & \multicolumn{3}{|c|}{ Average plastic limit } & \multicolumn{2}{|c|}{$0.00 \%$} \\
\hline
\end{tabular}


Characterization and Classification of Geotechnical Index Properties of Shallow Soil Deposits at Oworoshoki Area, Kosofe Local Government, Lagos, Nigeria

Table 4. Liquid limit cone penetrometer method at 3.0m depth

\begin{tabular}{|l|l|l|l|l|l|l|l|}
\hline Can No & 1 & 2 & 3 & 4 & 5 & 1 & 2 \\
Penetration & 4.7 & 9.8 & 13.9 & 18.6 & 23.0 & & \\
Can weight & 37.46 & 37.96 & 37.42 & 37.40 & 37.79 & \\
Weight of can +wet soil & 58.58 & 53.65 & 55.73 & 58.09 & 71.68 & \\
Weight of can +dry soil & 55.34 & 58.94 & 59.87 & 51.32 & 53.83 & \\
Weight of moisture & 3.24 & 4.71 & 5.86 & 6.77 & 7.85 & & \\
Moisture content & 17.88 & 20.98 & 22.45 & 23.92 & 26.04 & & \multirow{2}{*}{0.00} \\
\hline Liquid limit & 18.12 & 22.15 & 26.10 & 28.30 & 30.15 & 0.00 & $0.00 \%$ \\
\hline
\end{tabular}

Figure 2, 3 and 4 shows the Liquid Limit (LL) graph of penetration against moisture content at 1.0m, 2.0m and 3.0m respectively.

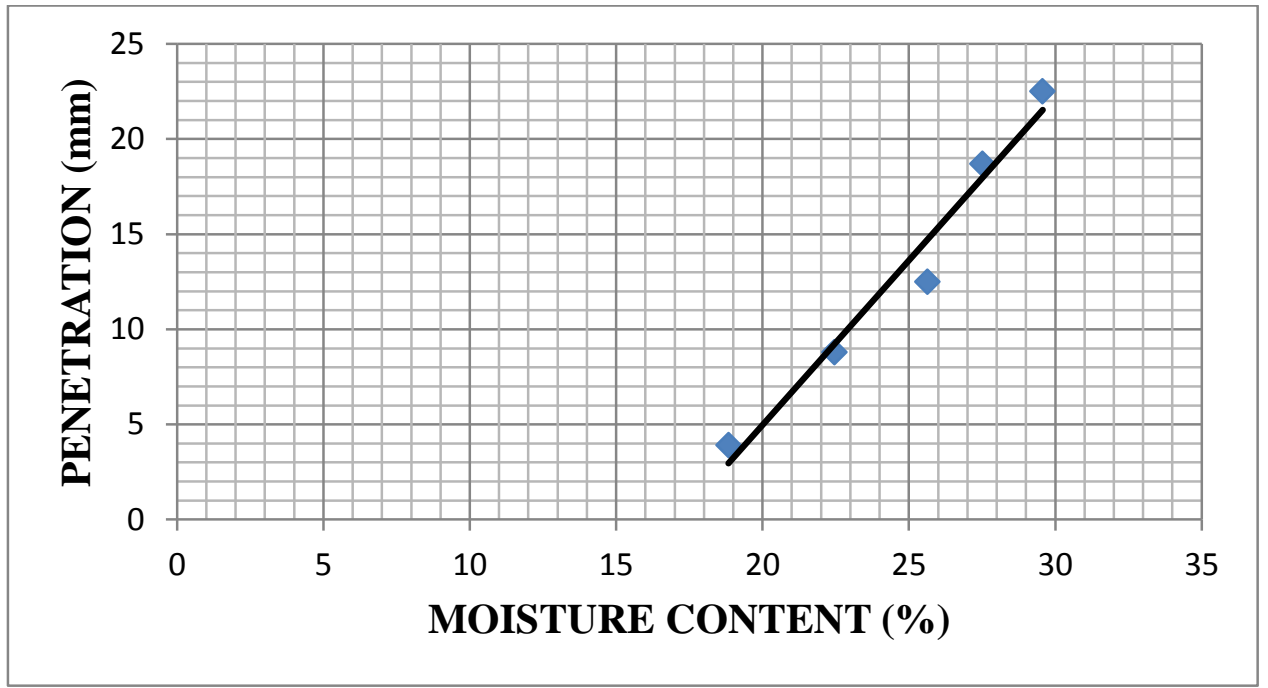

Figure 2: Liquid Limit at $1.0 \mathrm{~m}$

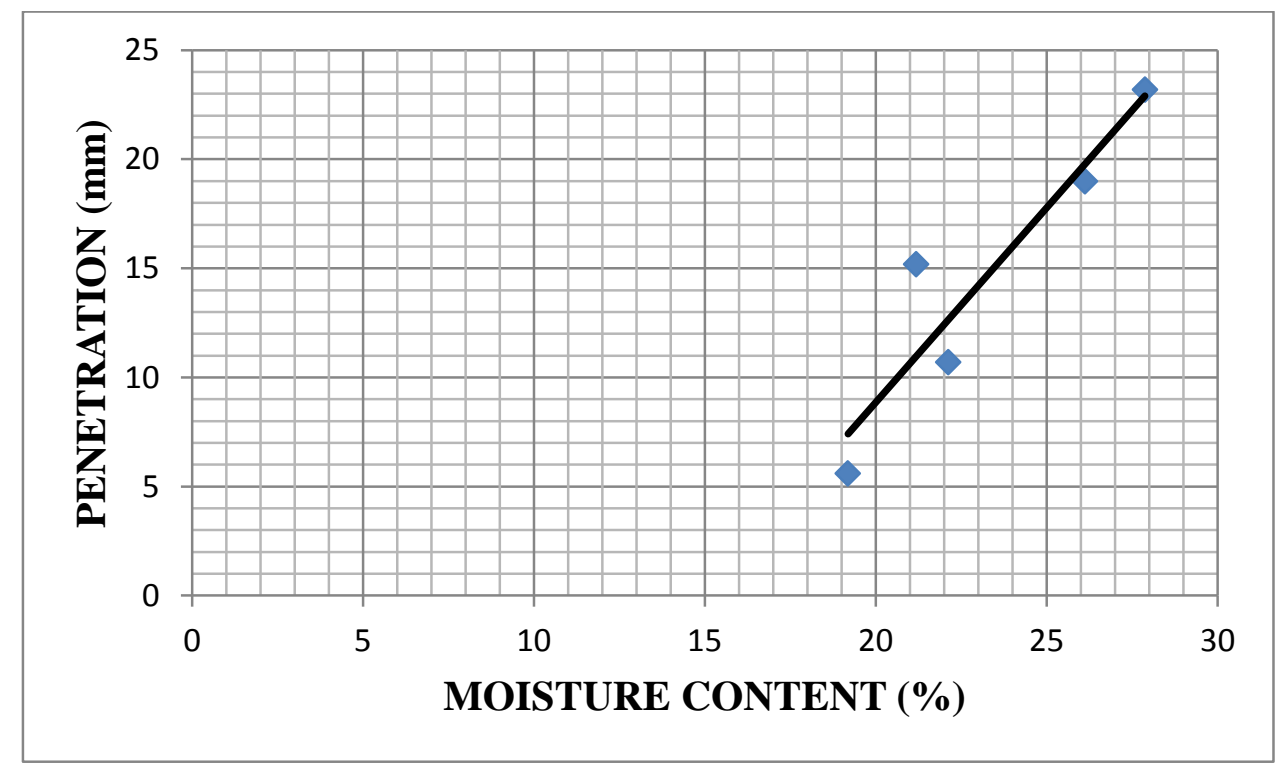

Figure 3: Liquid Limit at 2.0m 
Characterization and Classification of Geotechnical Index Properties of Shallow Soil Deposits at Oworoshoki Area, Kosofe Local Government, Lagos, Nigeria

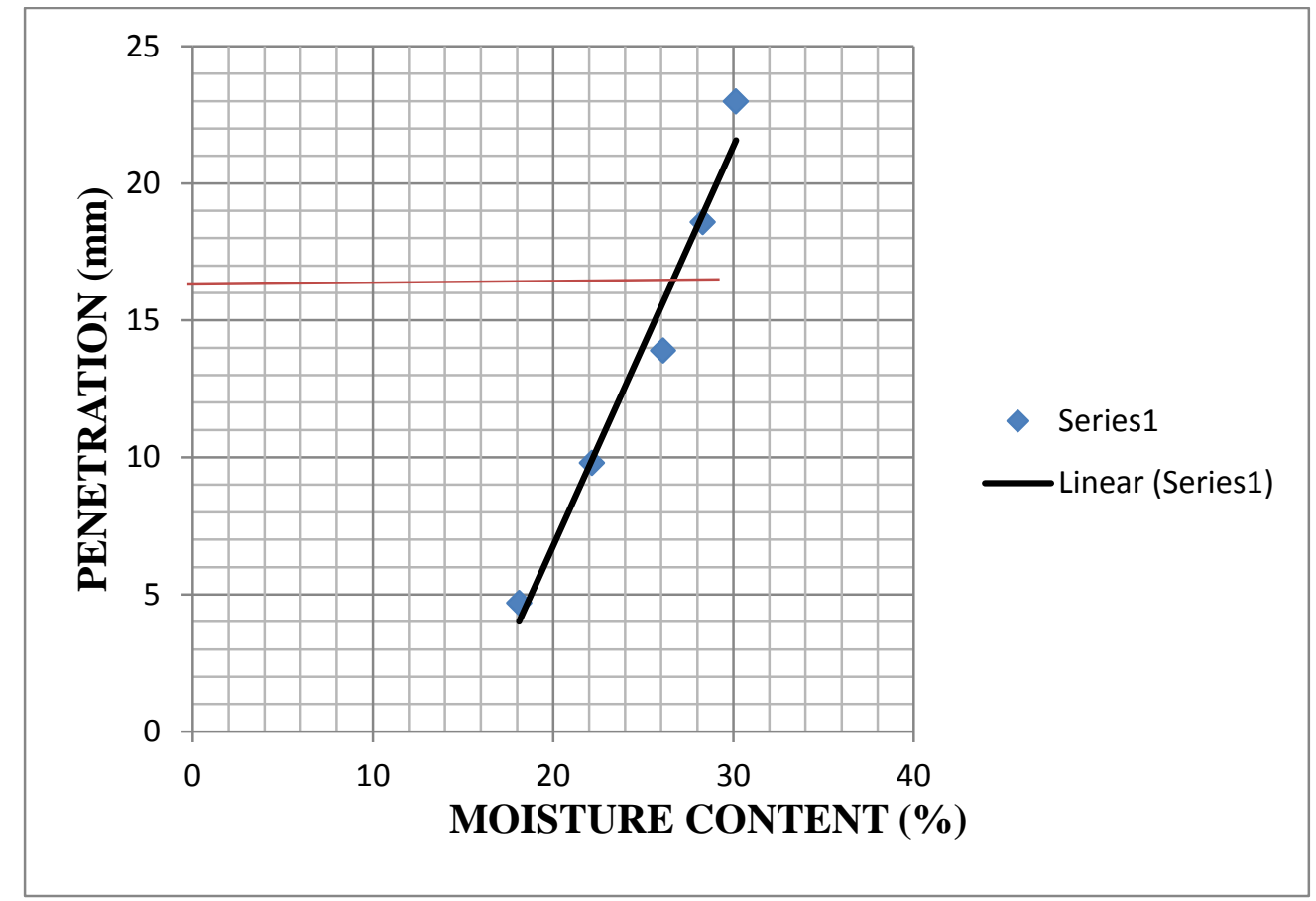

Figure 4: Liquid Limit at 3.0m

Table 5and 6 below shows Grain size analysis.

Table 5. Grain size analysis at $2.0 \mathrm{~m}$ depth

\begin{tabular}{|c|c|c|c|}
\hline $\begin{array}{l}\text { Sieve size } \\
(\mathrm{mm})\end{array}$ & $\begin{array}{l}\text { Mass } \\
\text { Retained (g) }\end{array}$ & $\begin{array}{l}\text { Percentage } \\
\text { Retained (\%) }\end{array}$ & $\begin{array}{l}\text { Percentage } \\
\text { Passing (\%) }\end{array}$ \\
\hline 5.000 & 0 & 0.00 & 100.00 \\
\hline 3.350 & 0 & 0.00 & 100.00 \\
\hline 2.000 & 0 & 0.00 & 100.00 \\
\hline 1.180 & 0.5 & 0.17 & 99.83 \\
\hline 0.850 & 0.3 & 0.10 & 99.73 \\
\hline 0.600 & 0 & 0.00 & 99.73 \\
\hline 0.425 & 0.2 & 0.07 & 99.67 \\
\hline 0.300 & 0 & 0.00 & 99.67 \\
\hline 0.150 & 0.7 & 0.23 & 99.43 \\
\hline 0.075 & 4.4 & 1.47 & 97.97 \\
\hline 0.030 & \multirow{7}{*}{\multicolumn{2}{|c|}{ Hydrometer Analysis }} & 92.32 \\
\hline 0.0021 & & & 87.12 \\
\hline 0.016 & & & 81.65 \\
\hline 0.011 & & & 75.13 \\
\hline 0.008 & & & 70.27 \\
\hline 0.007 & & & 66.16 \\
\hline 0.005 & & & 60.11 \\
\hline
\end{tabular}

Table 6. Grain size Analysis at 3.0m depth

\begin{tabular}{|l|l|l|l|}
\hline $\begin{array}{l}\text { Sieve size } \\
(\mathrm{mm})\end{array}$ & $\begin{array}{l}\text { Mass Retained } \\
(\mathrm{g})\end{array}$ & $\begin{array}{l}\text { Percentage } \\
\text { Retained (\%) }\end{array}$ & $\begin{array}{l}\text { Percentage } \\
\text { Passing }(\%)\end{array}$ \\
\hline 5.000 & 0 & 0.00 & 100.00 \\
3.350 & 0 & 0.00 & 100.00 \\
2.000 & 0 & 0.00 & 100.00 \\
1.180 & 0.2 & 0.7 & 99.93 \\
\hline
\end{tabular}


Characterization and Classification of Geotechnical Index Properties of Shallow Soil Deposits at Oworoshoki Area, Kosofe Local Government, Lagos, Nigeria

\begin{tabular}{|c|c|c|c|}
\hline 0.850 & 0.3 & 0.10 & 99.83 \\
\hline 0.600 & 0.2 & 0.07 & 00.77 \\
\hline 0.425 & 0.1 & 0.03 & 99.73 \\
\hline 0.300 & 0.1 & 0.03 & 99.70 \\
\hline 0.150 & 0.5 & 0.17 & 99.53 \\
\hline 0.075 & 4.3 & 1.43 & 98.10 \\
\hline 0.030 & \multirow{7}{*}{\multicolumn{2}{|c|}{ Hydrometer Analysis }} & 94.72 \\
\hline 0.021 & & & 89.45 \\
\hline 0.016 & & & 81.58 \\
\hline 0.011 & & & 76.10 \\
\hline 0.008 & & & 71.26 \\
\hline 0.007 & & & 67.18 \\
\hline 0.005 & & & 61.42 \\
\hline
\end{tabular}

Figure 5 below shows the sieve analysis graph of percentage passing against particle size at $1.0 \mathrm{~m}, 2.0 \mathrm{~m}$ and $3.0 \mathrm{~m}$ depth.

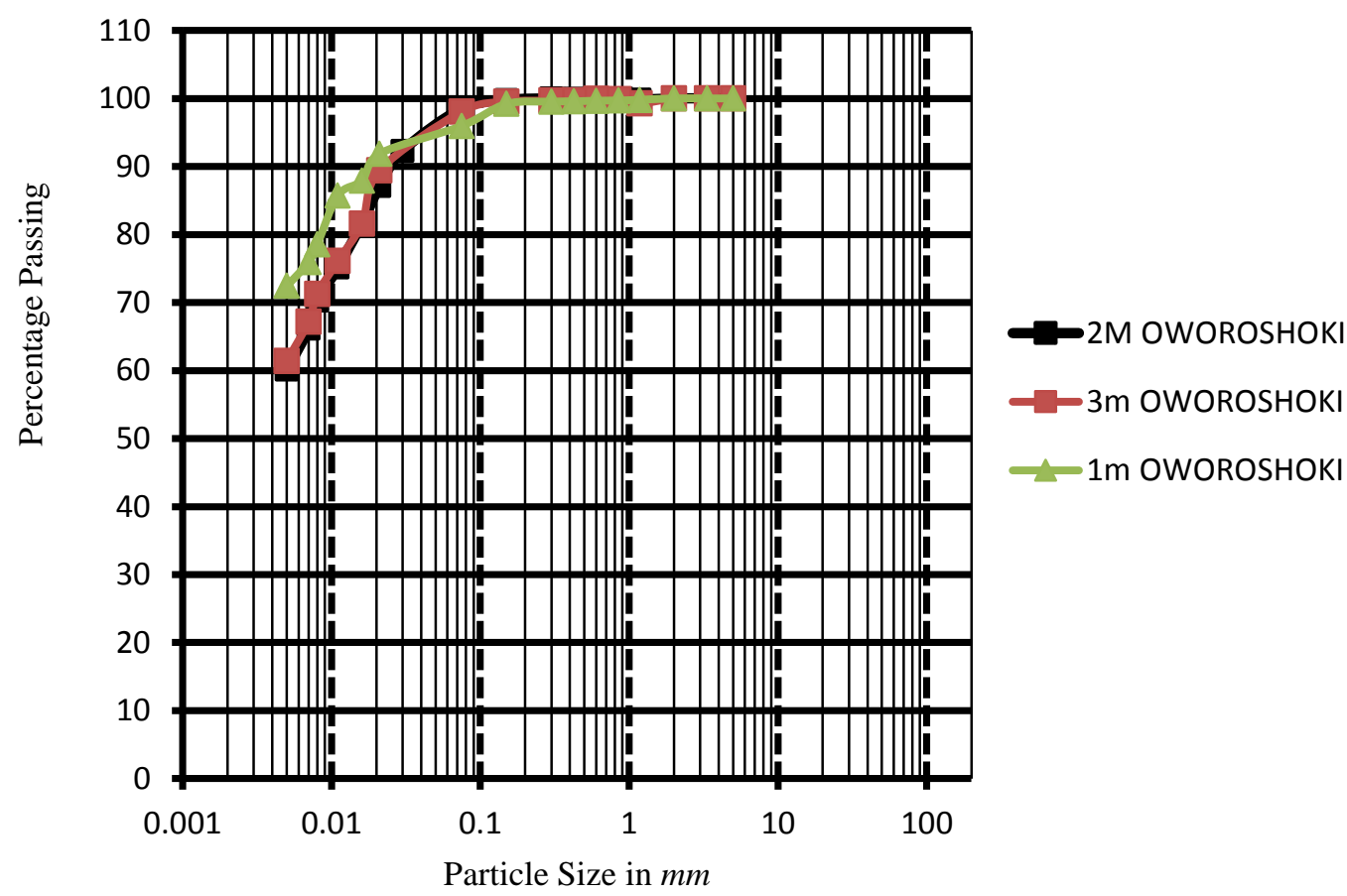

Figure 5: Sieve Analysis Graph

\section{Specific Gravity}

The specific gravity of soil sample at varying depths is presented in Table 7 below.

Table 7. Specific Gravity

\begin{tabular}{|l|l|}
\hline Depth $(\mathrm{m})$ & Specific gravity (Gs) \\
\hline 1.0 & 2.61 \\
\hline 2.0 & 2.55 \\
\hline 3.0 & 2.60 \\
\hline
\end{tabular}

Figure 6 below shows the specific gravity graph of specific gravity against depth at $1.0 \mathrm{~m}, 2.0 \mathrm{~m}$ and $3.0 \mathrm{~m}$ depth. 
Characterization and Classification of Geotechnical Index Properties of Shallow Soil Deposits at Oworoshoki Area, Kosofe Local Government, Lagos, Nigeria

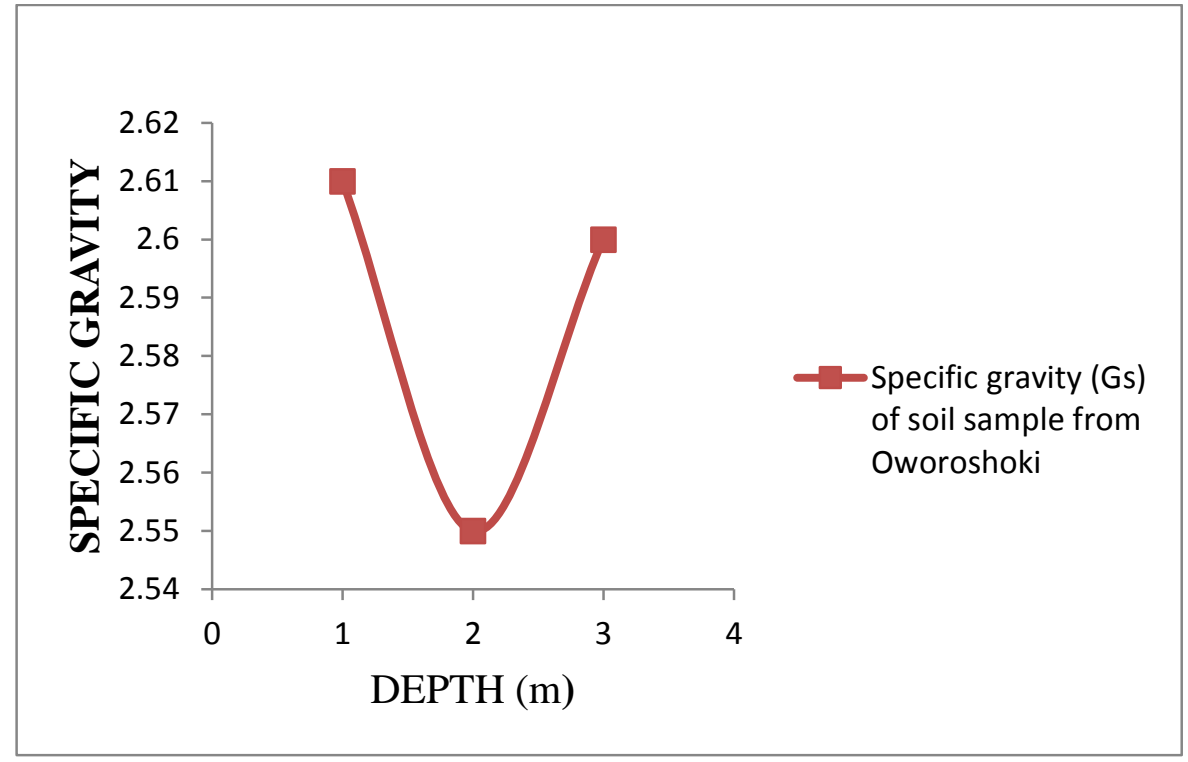

Figure 6: Specific Gravity Graph

\section{Unit Weight}

The Unit Weight of soil sample at varying depths $(1.0 \mathrm{~m}, 2.0 \mathrm{~m}$ and $3.0 \mathrm{~m})$ is presented in Table 8 below.

Table 8. Unit Weight

\begin{tabular}{|l|l|l|l|}
\hline Depth & 1 & 2 & 3 \\
Weight of mould (g) W1 & & & \\
W2 & & & \\
Weight of soil sample (g) W3 =(W2- & & & \\
W1) & & & \\
Volume $\left(\mathrm{cm}^{3}\right)$ & & 18.1 & 18.9 \\
Density $\mathrm{p} \mathrm{W3/volume}(\mathrm{g} / \mathrm{cm})$ & 17.5 & & \\
Unit weight $\mathrm{px9.81}\left(\mathrm{KN} / \mathrm{m}^{3}\right)$ & & \\
\hline
\end{tabular}

Figure7 below shows a graph of unit weight against depth at $1.0 \mathrm{~m}, 2.0 \mathrm{~m}$ and $3.0 \mathrm{~m}$.

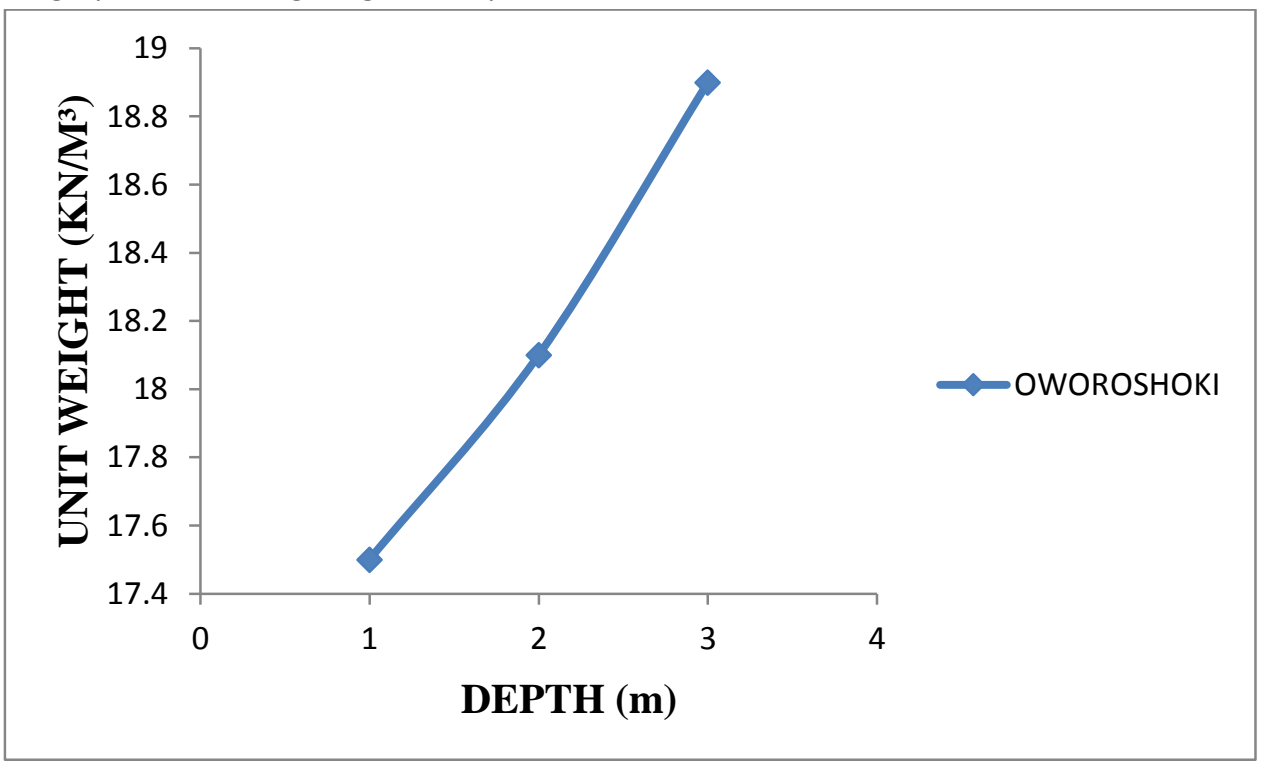

Figure 7: Unit Weight Graph 


\section{Characterization and Classification of Geotechnical Index Properties of Shallow Soil Deposits at Oworoshoki Area,}

Kosofe Local Government, Lagos, Nigeria

\section{Characterization}

The Characterization of soil sample at varying depths is presented in Table 9 below.

Table 9. Characterization of soil sample at $1.0 \mathrm{~m}, 2.0 \mathrm{~m}$ and $3.0 \mathrm{~m}$

\begin{tabular}{|l|l|l|l|}
\hline Characteristics & $1.0 \mathrm{~m}$ & $2.0 \mathrm{~m}$ & $3.0 \mathrm{~m}$ \\
\hline Natural Moisture content (\%) & 23.5 & 24.5 & 25.3 \\
\hline Specific Gravity & 2.61 & 2.55 & 2.60 \\
\hline Unit Weight $\left(\mathrm{KN} / \mathrm{m}^{3}\right)$ & 17.5 & 18.1 & 18.9 \\
\hline \% passing sieve 200(0.075mm) & 95.97 & 97.97 & 98.10 \\
\hline Liquid Limit \% & 28.68 & 26.64 & 29.10 \\
\hline Plastic Limit \% & - & - & - \\
\hline Plastic Index \% & - & - & - \\
\hline AASHTO Classification & A-3 & A-3 & A-3 \\
\hline
\end{tabular}

\section{DISCUSSION OF RESULTS}

The natural moisture content of Olworoshoki is given as $23.5 \%, 24.5 \%$ and $25.3 \%$. It has the highest retention capacity of water of $25.3 \%$ at $3.0 \mathrm{~m}$ depth. It has liquid limit of $28.68 \%, 26.64 \%$ and $29.10 \%$. Oworoshoki is non-plastic $(P I=0)$ for the three depths. Oworoshoki soil sample percentage passing through BS \#200 $(0.075 \mathrm{~mm})$ is $95.97 \%, 97.97 \%, 98.10 \%$. This shows that the soil sample contain much silt, the samples are non-plastic (NP) for all depths $(1 \mathrm{~m}, 2 \mathrm{~m}$ and $3 \mathrm{~m})$ and are classified as A-3. It has high percentage passing through BS \#200 $(0.075 \mathrm{~mm})$ with a value of $98.10 \%$. The specific gravity (Gs) of Oworoshoki is $2.61,2.55$ and 2.60. It has the unit weight of $17.5 \mathrm{KN} / \mathrm{m}^{3}, 18.1 \mathrm{KN} / \mathrm{m}^{3}$ and $18.9 \mathrm{KN} / \mathrm{m}^{3}$. Hydrometer test is only conducted when an appreciable quantity of soil sample passes through BS \#200 $(0.075 \mathrm{~mm})$. Base on this fact Oworoshoki soil samples were tested for hydrometer.

\section{CONCLUSION}

The result of soil samples has revealed the characteristics of the soil within the study area. It has shown that the area is dominated by silt soil because the percentage passing BS \#200 $(0.075 \mathrm{~mm})$ at depth $1.0 \mathrm{~m}, 2.0 \mathrm{~m}$ and $3.0 \mathrm{~m}$ is $95.97 \%, 97.97 \%$ and $98.10 \%$ respectively which is greater than $35 \%$. The soil sample at depth $1.0 \mathrm{~m}, 2.0 \mathrm{~m}$ and $3.0 \mathrm{~m}$ are nonplastic (NP) because the Plastic Index $(\mathrm{PI}=0)$ therefore the AASHTO classification of the soil is A - 3.Silt soil has low load bearing capacity compare to that of coarse soil which has high load bearing capacity. Since an appreciable quantity of soil has passed through BS \#200 $(0.075 \mathrm{~mm})$, hydrometer test becomes necessary and was conducted. It shows that the soil contain high amount of silt.

\section{REFERENCES}

1) Akpokodje, E.G. (1989). Preliminary Studies of the Niger Delta sub soils. Engineering Geology, No. 26, Pp. 247 - 257.

2) Akpokodje, E.G. (2001).Introduction to Engineering Geology Properties of Earth Materials. Engineering Geology, Port Harcourt, Pp. $1-147$.

3) Arora, K.R. (2008).Soil Mechanics and Foundation Engineering (Geotechnical Engineering), Standard Publishers Distributors, Delhi.

4) Christodoulias, J. (2015). Engineering Properties and Shrinkage Limit of Swelling Soils in Greece. Journal of Earth Science and Climate Change, 6(5):279 doi: 104172/2157-7617.1000279.

5) Jain, V.K., Dixit, M. and Chitra, R. (2015).Correlation of plasticity index and compression index of soil.IJIET, 5(3): 263270.

6) Laskar, A. and Pal, S.K. (2012).Geotechnical characteristics of two different soils and their mixture and relationships between parameters. EJGE, 17: 2821-2832.

7) Nwankwoala, H.O. and Warmate, T. (2014). Geotechnical assessment of foundation conditions of a site in Ubima, Ikwerre Local Government Area, Rivers State, Nigeria, IJERD, 9(8): 50 - 63.

8) Oghenero, A.E., Akpokodje, E.G. and Tse, A.C. (2014).Geotechnical properties of subsurface soils in Warri, Western Niger Delta, Nigeria. Journal of Earth Sciences and Geotechnical Engineering, 4(1): 89 - 102.

9) Oke, S.A. and Amadi, A.N. (2008).An assessment of the geotechnical properties of the sub-soil of parts of Federal University of Technology, Minna, GidanKwano Campus, for foundation design and construction. JSciEducTechnol, 1 (2): $87-102$. 
Characterization and Classification of Geotechnical Index Properties of Shallow Soil Deposits at Oworoshoki Area, Kosofe Local Government, Lagos, Nigeria

10) Oyediran, I. A. and Durojaiye, H. F. (2011). Variability in the Geotechnical properties of some residual clay soils from south western Nigeria. International Journal of Scientific \& Engineering Research Volume 2: 2229-5518.

11) Rorome, O. and Ekeocha, N.E. (2015).The Geotechnical Index Properties of soil in Warri, Delta State, Nigeria. Department of Geology, University of Port Harcourt, Port Harcourt, Nigeria. International Journal of Science Inventions Today, 4(1): 85-91.

12) Smith, M.J. (1994). Soil Mechanics. ${ }^{\text {th }}$ edition, Pp. 44 - 45. South Bank, England. Longman Singapore Publishers (Plc) Ltd.

13) Surendra, R.(2017).Role of Geotechnical Properties of Soil on Civil Engineering Structures. Journal of Scientific and Academic Publishing, 7(4):103 - 109,doi:10.5923/j.re.20170704.03.

14) Yoon, T.C., Yunus, N.Z.M., Marto, A., Hezmi, M.A., Jusoh, N.S and Ahmad, K. (2015). Comparison of soil index properties values for different pre - drying conditions on clayey soil. Journal of Technology: DOI: 10.11113/jt.v76.5429. 